\title{
PENGARUH PENGGUNAAN MODEL PEMBELAJARAN DAN ASESMEN KINERJA TERHADAP KEMAMPUAN PEMECAHAN MASALAH MATEMATIKA
}

\author{
ANDRI SURYANA \\ 081381240205 \\ andri_16061983@yahoo.com \\ Program Studi Pendidikan Biologi, Fakultas Teknik, Matematika dan IPA \\ Universitas Indraprasta PGRI
}

\begin{abstract}
The objective of this research is to study the effects of learning model and performance assessment model on mathematics problem solving (subject of calculus). An experimental research was conducted at Biology education-UNINDRA.They were selected through multistage random sampling technique. Problem solving test has been employed to collect data which was analyzed by means of two way analysis of variance (ANOVA). Research findings concluded that (1) students who learn under the cooperative learning model show higher then classical learning model in mathematics problem solving (subject of calculus), (2) students receiving Lane Holistic's performance assessment show higher then Polya's performance assessment on mathematics problem solving (subject of calculus), (3) there are interaction between learning model, performance assessment model, and mathematics problem solving, (4) in the cooperative learning models group, students receiving Lane Holistic's performance assessment show lower then Polya's performance assessment on mathematics problem solving (subject of calculus), (5) in the classical learning models group, students receiving Lane Holistic's performance assessment show higher then Polya's performance assessment on mathematics problem solving (subject of calculus), (6) students who are taught mathematics with Lane Holistic's performance assessment, students who learn under the cooperative learning model show lower then classical learning model in mathematics problem solving (subject of calculus), and (7) students who are taught mathematics with Polya's performance assessment, students who learn under the cooperative learning model show higher then classical learning model in mathematics problem solving (subject of calculus).
\end{abstract}

Keywords: learning model, performance assessment model, Lane Holistic, Polya, mathematics problem solving

\section{PENDAHULUAN}

Kemampuan matematika pada mahasiswa Program Studi Pendidikan Biologi saat ini belum dapat dikatakan tinggi. Hal ini terbukti dari Kartu Hasil Studi (KHS) untuk mata kuliah eksak, seperti halnya Kalkulus, Statistika, Fisika Dasar, dan Kimia Dasar yang notabene memerlukan keahlian matematika yang cukup tinggi justru masih banyak yang nilainya kurang maksimal. Rendahnya kemampuan matematika menyebabkan munculnya sikap ketidaksenangan mahasiswa terhadap mata kuliah eksak. Hal ini disebabkan oleh SAP yang padat, media belajar yang kurang efektif, metode pengajaran tradisional yang tidak interaktif, dan buruknya sistem penilaian yang hanya mengejar solusi tetapi mengabaikan proses mendapatkan solusi. Adapun metode, model dan evaluasi pembelajaran yang dikuasai dosen selama ini belum beranjak dari pola tradisional, dan hal ini berdampak negatif terhadap daya serap mahasiswa yang ternyata 
masih lemah. Hal ini terjadi pada hampir seluruh mata kuliah, termasuk mata kuliah Kalkulus.

Pembelajaran matematika pola tradisional dilakukan secara klasikal dengan berpusat pada dosen. Mahasiswa dianggap tidak memiliki kemampuan awal, bahkan tidak diberi kesempatan untuk menyampaikan inisiatif. Kondisi ini menyebabkan mahasiswa seperti sebuah mesin yang akan belajar apabila diperintahkan oleh dosen. Dosen menyiasati kondisi ini dengan memberikan tugas terstruktur yang relatif banyak kepada mahasiswa agar mereka mau belajar. Pembelajaran dengan cara seperti ini akan berdampak pada penurunan kreativitas mahasiswa, motivasi belajar rendah, dan mata kuliah Kalkulus menjadi menakutkan.

Di dalam pembelajaran matematika, interaksi antar mahasiswa seperti halnya komunikasi dosen dengan mahasiswa merupakan bagian penting untuk mengembangkan potensi matematika mahasiswa. Salah satu model pembelajaran yang sesuai dengan tuntutan tersebut adalah pembelajaran kooperatif yang bertujuan mengembangkan kemahiran dan kecakapan matematika dalam pemahaman konsep untuk pemecahan masalah. Pemecahan masalah merupakan aktivitas penting dalam kegiatan belajar matematika. Untuk meningkatkan kemampuan dalam pemecahan masalah, perlu diciptakan situasi pembelajaran yang mendorong mahasiswa memainkan peran aktif dalam memperoleh pengetahuan, serta menggunakan ide matematika yang dimilikinya.

Selain itu, pemberian asesmen atau penilaian pembelajaran hendaknya tidak hanya dilaksanakan pada akhir satuan waktu pendidikan dengan menggunakan kertas dan pensil saja, melainkan harus dilakukan secara terus-menerus dengan menerapkan asesmen otentik (authentic assessment) yang salah satunya adalah asesmen kinerja (performance assessment). Asesmen kinerja memberi kontribusi langsung pada proses pembelajaran karena kedua komponennya, yaitu tugas (task) dan rubrik (rubric) dikembangkan bersama-sama oleh dosen dan mahasiswa sehingga mereka telah sepakat dalam hal penilaian.

Dengan mempertimbangkan beberapa hal di atas, maka fokus dari penelitian ini adalah peningkatan kemampuan pemecahan masalah dalam mata kuliah Kalkulus pada mahasiswa Program Studi Pendidikan Biologi FTMIPA UNINDRA yang akan diupayakan melalui penerapan model pembelajaran kooperatif dengan asesmen kinerja yang telah banyak dikembangkan oleh beberapa tokoh, dua diantaranya oleh Suzanne Lane dan G. Polya.

\section{TINJAUAN PUSTAKA}

\section{Kemampuan Pemecahan Masalah Matematika}

Menurut Bell (1978), suatu situasi dikatakan masalah bagi seseorang apabila ia sadar akan keberadaan situasi tersebut, mengakui bahwa situasi tersebut memerlukan tindakan, ia mau dan perlu melakukan tindakan, serta situasi itu tidak segera dapat ditemukan pemecahannya. Hayes dalam Hengenson (1992) menyatakan bahwa suatu masalah merupakan kesenjangan antara keadaan sekarang dengan tujuan yang ingin dicapai, sedangkan belum diketahui cara tertentu untuk mencapai tujuan tersebut. Hawton (1992) menegaskan bahwa masalah merupakan pertanyaan yang harus dijawab pada saat itu sedangkan belum ada rencana solusi yang jelas. Menurut Hudoyo (1990), masalah matematika dibedakan menjadi dua hal, yaitu (1) latihan yang diberikan pada waktu belajar matematika agar terampil atau sebagai aplikasi dari pengertian yang baru diajarkan, dan (2) masalah yang tidak seperti halnya latihan melainkan menghendaki siswa untuk menggunakan sintesis atau analisis.

Dari beberapa pendapat para ahli yang dikemukakan sebelumnya, maka masalah matematika merupakan suatu soal atau pertanyaan matematika apabila mahasiswa belum 
dapat menyelesaikannya pada saat itu dan mempunyai keinginan maupun keperluan untuk melakukannya.

Pemecahan masalah merupakan suatu aktivitas penting dalam kegiatan belajar matematika. Cooney (1975) menyatakan bahwa pemecahan masalah adalah proses diterimanya tantangan dan bekerja keras untuk menyelesaikan masalah tersebut. Polya (1985) mengartikan pemecahan masalah sebagai suatu usaha mencari jalan keluar dari suatu kesulitan guna mencapai suatu tujuan yang tidak begitu mudah segera dapat dicapai. Menurut Dess (1996), pemecahan masalah merupakan suatu kegiatan manusia dalam menerapkan konsep dan aturan yang diperoleh sebelumnya. Baroody dan Niskayuna (1993) mengelompokkan pendekatan pemecahan masalah dalam pembelajaran matematika menjadi tiga hal yang berbeda, yaitu teaching via problem solving, teaching about problem solving, dan teaching for problem solving.

Dari beberapa pendapat para ahli yang dikemukakan sebelumnya, maka kemampuan pemecahan masalah matematika yang akan diukur merupakan daya upaya atau usaha dari seseorang untuk menyelesaikan masalah matematika yang dihadapi menggunakan metode, prosedur, langkah-langkah, serta strategi yang dapat dipertanggungjawabkan secara matematis.

\section{Model Pembelajaran}

Menurut Joyce dan Weil (1996), model pembelajaran merupakan suatu rencana atau pola yang dapat digunakan untuk membantu mahasiswa memperoleh informasi, ideide, keterampilan-keterampilan, nilai-nilai, cara berpikir, makna ekspresi diri serta mangajarkan bagaimana belajar. Di samping itu, Joyce dan Weil (1996) juga menyatakan bahwa suatu model pembelajaran merupakan deskripsi dari lingkungan belajar yang dapat digunakan untuk merancang kurikulum sampai dengan memilih bahan-bahan guna desain pembelajaran. Reigeluth (1983) mengembangkan model pembelajaran secara komprehensif yang terdiri atas tiga variabel utama, yaitu: (1) kondisi pembelajaran (instructional conditions), (2) metode pembelajaran (instructional methods), dan (3) hasil pembelajaran (instructional outcomes).

Berdasarkan pendapat para ahli di atas, maka model pembelajaran dapat disimpulkan sebagai pola umum yang terdiri dari urutan kegiatan, metode dan media untuk menyusun suatu materi pembelajaran dengan mengkondisikan mahasiswa belajar secara efektif guna mencapai tujuan yang ditetapkan.

Adapun model pembelajaran yang digunakan dalam penelitian ini adalah

\section{a. Model Pembelajaran Klasikal}

Menurut Ruseffendi (1988), para mahasiswa di dalam model klasikal diasumsikan memiliki kesamaan-kesamaan dalam hal kemampuan awal atau kemampuan prasyarat, minat, kepentingan dan kecepatan belajar. Chang dan Simon (1999) menyatakan bahwa pembelajaran secara klasikal adalah suatu kegiatan mandiri secara fisik yang dilakukan di dalam kamar, ruang kelas atau ruang kantor, termasuk dalam hal ini adalah kegiatan membaca, menulis, memecahkan masalah dan pengamatan secara mandiri. Stahl (1994) memberikan ciri-ciri pembelajaran klasikal, yaitu: (1) bekerja untuk diri sendiri, (2) pandangan mahasiswa ke papan tulis dengan penuh perhatian, (3) mendengarkan dosen dengan seksama, (4) materi belajar diperoleh dari dosen atau bahan ajar, (5) bekerja secara individu, (6) berkonsentrasi dalam belajar, (7) hanya dosen yang membuat keputusan, serta (8) mahasiswa pasif.

Dengan demikian, model pembelajaran klasikal merupakan model pembelajaran di mana materi disajikan dalam suatu ruangan kelas dengan aktivitas mengajar berpusat pada dosen, menekankan pada tugas dan tanggung 
jawab masing-masing individu tanpa adanya kerja sama dalam kelompok kecil atau kerja sama antar mahasiswa.

\section{b. Model Pembelajaran Kooperatif}

Terkait dengan interaksi antar mahasiswa di dalam proses pembelajaran, Johnson dan Johnson (1987) menyatakan bahwa model pembelajaran kooperatif menekankan adanya kerja sama, yakni kerja sama antar mahasiswa dalam kelompok untuk mencapai tujuan belajar. Stahl (1994) merinci ciri-ciri pembelajaran kooperatif, yaitu: (1) mahasiswa belajar bersama teman, (2) selama proses belajar terjadi tatap muka dengan teman, (3) saling mendengarkan pendapat antar anggota kelompok, (4) belajar dengan teman satu kelompok, (5) belajar dalam kelompok kecil, (6) produktif berbicara atau saling mengemukakan pendapat, (7) keputusan tergantung mahasiswa, serta (8) mahasiswa aktif. Kelebihan lain model kooperatif diberikan oleh Hilke (1994), yaitu : (1) meningkatkan kerja sama akademik antar mahasiswa, (2) membentuk hubungan positif, (3) mengembangkan rasa percaya diri, serta (4) meningkatkan kemampuan akademik.

Dengan demikian, model pembelajaran kooperatif merupakan model pembelajaran yang menempatkan aktivitas mahasiswa sebagai hal yang utama, oleh karenanya diberikan kesempatan yang seluas-luasnya kepada mahasiswa untuk mengkaji lebih mendalam materi pembelajaran, dengan demikian proses konstruksi pengetahuan akan terjadi dengan lebih baik.

\section{Asesmen Kinerja}

Nitko (1996) mendefinisikan asesmen sebagai suatu proses untuk mendapatkan informasi yang dapat digunakan untuk membuat keputusan mengenai mahasiswa, kurikulum dan program, serta kebijakan pendidikan. Huba dan Freed (1999) menyatakan bahwa asesmen adalah proses pengumpulan dan diskusi informasi dari berbagai macam sumber untuk mengembangkan pengertian mendalam dari apa yang diketahui, dipahami dan apa yang dapat diperbuat mahasiswa dengan pengetahuannya sebagai hasil pengalaman pendidikannya. Cal Poly (1999) juga menyatakan bahwa asesmen pembelajaran adalah suatu proses kontinu yang bertujuan mengetahui dan meningkatkan belajar mahasiswa.

Dengan demikian, asesmen dapat disimpulkan sebagai suatu proses untuk mendapatkan informasi dalam mengembangkan pengertian mendalam dari apa yang diketahui sehingga dapat meningkatkan belajar mahasiswa.

Asesmen kinerja menurut Nitko (1996) didefinisikan sebagai suatu prosedur penugasan kepada mahasiswa guna mengumpulkan informasi sejauh mana mahasiswa telah belajar. Menurut Zainul (2004), asesmen kinerja memiliki dua komponen yang dikembangkan bersama oleh dosen dan mahasiswa. Kedua komponen tersebut adalah tugas-tugas (tasks) dan perangkat kriteria penskoran yang disebut rubrik (rubric). Tugastugas kinerja (performance tasks) menurut Nitko (1996) merupakan aktivitas yang menghendaki mahasiswa menampilkan prestasinya dari sebuah target pembelajaran. Rubrik (Scoring Rubrics) menurut Zimaro (1999) merupakan pedoman penilaian sistematis untuk menilai kinerja mahasiswa (paper, ucapan, jawaban soal, portofolio, dan kasus) melalui penggunaan deskripsi yang detail dari standar kinerja.

Dengan demikian, asesmen kinerja dapat disimpulkan sebagai suatu prosedur penugasan yang memberikan kontribusi langsung pada proses pembelajaran karena kedua komponennya, yaitu tugas (task) dan rubrik (rubric) yang dikembangkan bersama-sama oleh dosen dan mahasiswa sehingga mereka telah sepakat dalam hal penilaian.

Adapun asesmen kinerja yang digunakan dalam penelitian ini adalah 


\section{a. Asesmen Kinerja Holistik dari Lane}

Asesmen kinerja holistik dari Lane (1992) adalah penyelesaian masalah atau tugas matematika melalui 3 tahap, yaitu: (1) mengidentifikasi pengetahuan matematika, (2) menentukan dan menerapkan pengetahuan strategi penyelesaian masalah, serta (3) mengkomunikasikan hasil penyelesaian masalah.

\section{b. Asesmen Kinerja Menurut Polya}

Asesmen kinerja menurut Polya (1981) adalah penyelesaian masalah atau tugas matematika melalui 4 tahap, yaitu: (1) memahami masalah, (2) merencanakan prosedur penyelesaian, (3) melaksanakan rencana, serta (4) memeriksa hasil dan proses.

\section{Hipotesis Penelitian}

Berdasarkan permasalahan di atas, maka dapat dirumuskan hipotesis penelitian sebagai berikut :

1) Kemampuan pemecahan masalah matematika untuk mahasiswa yang memperoleh pembelajaran dengan model kooperatif lebih tinggi dibandingkan mahasiswa yang memperoleh pembelajaran dengan model klasikal dalam mata kuliah Kalkulus.

2) Kemampuan pemecahan masalah matematika untuk mahasiswa yang diberi asesmen kinerja holistik dari Lane lebih tinggi dibandingkan mahasiswa yang diberi asesmen kinerja menurut Polya dalam mata kuliah Kalkulus.

3) Adanya interaksi antara penggunaan model pembelajaran dan asesmen kinerja terhadap kemampuan pemecahan masalah matematika dalam mata kuliah Kalkulus.

4) Pada kelompok mahasiswa yang memperoleh pembelajaran dengan model kooperatif, kemampuan pemecahan masalah matematika untuk mahasiswa yang diberi asesmen kinerja holistik dari Lane lebih rendah dibandingkan mahasiswa yang diberi asesmen kinerja menurut Polya dalam mata kuliah Kalkulus.

5) Pada kelompok mahasiswa yang memperoleh pembelajaran dengan model klasikal, kemampuan pemecahan masalah matematika untuk mahasiswa yang diberi asesmen kinerja holistik dari Lane lebih tinggi dibandingkan mahasiswa yang diberi asesmen kinerja menurut Polya dalam mata kuliah Kalkulus.

6) Pada kelompok mahasiswa yang diberi asesmen kinerja holistik dari Lane, kemampuan pemecahan masalah matematika untuk mahasiswa yang memperoleh pembelajaran dengan model kooperatif lebih rendah dibandingkan mahasiswa yang memperoleh pembelajaran dengan model klasikal dalam mata kuliah Kalkulus.

7) Pada kelompok mahasiswa yang diberi asesmen kinerja menurut Polya, kemampuan pemecahan masalah matematika untuk mahasiswa yang memperoleh pembelajaran dengan model kooperatif lebih tinggi dibandingkan mahasiswa yang memperoleh pembelajaran dengan model klasikal dalam mata kuliah Kalkulus.

\section{METODE}

\section{Metode dan Desain Penelitian}

Penelitian ini menggunakan metode quasi eksperimen. Variabel penelitian meliputi variabel bebas dan variabel terikat. Variabel bebas terdiri atas model pembelajaran $\left(X_{1}\right)$ dan asesmen kinerja $\left(X_{2}\right)$, sedangkan variabel terikatnya adalah kemampuan pemecahan masalah matematika.

Penelitian ini menggunakan Desain Faktorial 2x2. Untuk analisis statistika inferensia digunakan ANOVA Dua Arah. Adapun desain penelitiannya dapat dilihat pada Tabel 1 . 
Tabel 1. Desain Penelitian Eksperimen Faktorial 2x2

\begin{tabular}{|c|c|c|c|}
\cline { 2 - 3 } \multicolumn{1}{c|}{} & \multicolumn{2}{|c|}{$\begin{array}{c}\text { Model Pembelajaran } \\
(\mathrm{A})\end{array}$} & $\sum Y_{i}$ \\
\hline $\begin{array}{c}\text { Asesmen } \\
\text { Kinerja } \\
(\mathrm{B})\end{array}$ & $\begin{array}{c}\text { Kooperatif } \\
\left(\mathrm{A}_{1}\right)\end{array}$ & $\begin{array}{c}\text { Klasikal } \\
\left(\mathrm{A}_{2}\right)\end{array}$ & \\
\hline Lane $\left(\mathrm{B}_{1}\right)$ & $Y_{11}$ & $Y_{21}$ & $Y_{* 1}$ \\
\hline Polya $\left(\mathrm{B}_{2}\right)$ & $Y_{12}$ & $Y_{22}$ & $Y_{* 2}$ \\
\hline$\sum Y_{i}$ & $Y_{1^{*}}$ & $Y_{2^{*}}$ & $Y_{* *}$ \\
\hline
\end{tabular}

\section{Populasi dan Teknik Pengambilan Sampel}

Populasi target dalam penelitian ini adalah seluruh mahasiswa peserta Kalkulus Program Studi Pendidikan Biologi. Adapun populasi terjangkaunya adalah mahasiswa peserta Kalkulus Semester II tahun ajaran 2009/2010.

Penentuan sampel menggunakan teknik Multi Stage Random Sampling dengan langkah-langkah sebagai berikut :

1) Secara acak diambil 4 kelas, yaitu 2 kelas untuk diberi perlakuan pembelajaran kooperatif dan 2 kelas berikutnya untuk diberi perlakuan pembelajaran klasikal.

2) Untuk 2 kelas yang akan diberi perlakuan pembelajaran kooperatif, diundi lagi dan ditetapkan 1 kelas sebagai kelompok mahasiswa yang akan diberi perlakuan asesmen kinerja menurut Polya dan sisanya sebagai kelompok mahasiswa yang akan diberi perlakuan asesmen kinerja holistik dari Lane.

3) Untuk 2 kelas yang akan diberi perlakuan pembelajaran klasikal, diundi lagi dan ditetapkan 1 kelas sebagai kelompok mahasiswa yang akan diberi perlakuan asesmen kinerja menurut Polya dan sisanya sebagai kelompok mahasiswa yang akan diberi perlakuan asesmen kinerja holistik dari Lane.

4) Untuk masing-masing kelas dipilih lagi secara acak sebagai subjek penelitian sebanyak 15 mahasiswa.

\section{Teknik Pengumpulan Data}

Data yang dikumpulkan dalam penelitian ini ada 3 macam, yaitu :

1) Data hasil tes kemampuan pemecahan masalah.

2) Data asesmen kinerja mahasiswa menurut Polya/secara holistik dari Lane.

3) Model pembelajaran.

Data hasil tes kemampuan pemecahan masalah matematika bersumber dari mahasiswa yang menjadi sampel penelitian yang dikumpulkan dengan menggunakan tes kemampuan yang telah dikembangkan peneliti. Data asesmen kinerja mahasiswa menurut Polya/secara holistik dari Lane bersumber dari mahasiswa yang menjadi sampel penelitian yang dikumpulkan dengan menggunakan pedoman penskoran (rubrik) yang telah dikembangkan oleh masing-masing tokoh, yaitu Polya dan Lane. Model pembelajaran bersumber dari literatur/dokumen yang diambil dengan teknik dokumentasi.

Pengukuran kemampuan pemecahan masalah matematika dilakukan setelah proses perlakuan eksperimen selesai dilaksanakan. Pengukuran asesmen kinerja dilakukan pada setiap pertemuan pembelajaran berdasarkan tugas (task) yang diberikan di dalam kelas. 


\section{Teknik Analisis Data}

Analisis data yang digunakan meliputi:

1) Analisis deskriptif, yaitu bentuk tabel distribusi frekuensi, rata-rata (mean), median, modus, ragam dan simpangan baku.

2) Analisis uji persyaratan data, yaitu uji normalitas data dan uji homogenitas.

3) Analisis inferensia, yaitu menggunakan Two Way ANOVA dengan desain eksperimen faktorial $2 \times 2$. Uji lanjutan untuk membandingkan perbedaan pengaruh antar kelompok sebagai konsekuensi adanya interaksi digunakan Uji $t$.

\section{HASIL DAN PEMBAHASAN}

Berdasarkan hasil uji coba yang dilakukan terhadap 30 mahasiswa, ternyata dari 15 soal essay instrumen kemampuan pemecahan masalah matematika pada mata kuliah Kalkulus yang dinyatakan valid hanya sebanyak 10 soal. Ke-10 soal yang valid tersebut selanjutnya diberikan ke sampel penelitian.

Adapun deskripsi statistik dari data hasil penelitian yang diperoleh dari sampel penelitian dapat dilihat pada Tabel 2 .

Tabel 2. Deskripsi Statistik Data Penelitian

\begin{tabular}{|c|c|c|c|}
\hline$\underbrace{\begin{array}{r}\text { Model } \\
\text { Pembelajaran }\end{array}}_{\begin{array}{l}\text { Asesmen } \\
\text { Kinerja }\end{array}}$ & $\begin{array}{c}\text { Kooperatif } \\
\left(A_{1}\right)\end{array}$ & $\begin{array}{c}\text { Klasikal } \\
\left(A_{2}\right)\end{array}$ & Jumlah \\
\hline $\begin{array}{l}\text { Lane } \\
\left(B_{1}\right)\end{array}$ & $\begin{array}{l}n_{A B}=15 \\
\bar{X}_{A B}=60,67 \\
s_{A B}^{2}=117,38\end{array}$ & $\begin{array}{l}n_{A_{i, B}}=15 \\
\bar{X}_{A_{1} B_{1}}=71,33 \\
s_{A_{i, B_{1}}}^{2}=83,81\end{array}$ & $\begin{array}{l}n_{B_{1}}=30 \\
\bar{X}_{B_{1}}=66 \\
s_{B_{B}}^{2}=126,55\end{array}$ \\
\hline $\begin{array}{c}\text { Polya } \\
\left(B_{2}\right)\end{array}$ & $\begin{array}{l}n_{A B_{2}}=15 \\
\bar{X}_{A B_{2}}=72,67 \\
s_{A B_{2}}^{2}=74,52\end{array}$ & $\begin{array}{l}n_{A_{1} B_{2}}=15 \\
\bar{X}_{A_{B_{1} B_{2}}}=48 \\
s_{A_{A_{3}}}^{2}=110\end{array}$ & $\begin{array}{l}n_{B_{B_{2}}}=30 \\
\bar{X}_{B_{B_{2}}}=60,33 \\
s_{B_{B_{2}}}^{2}=246,44\end{array}$ \\
\hline Jumlah & $\begin{array}{l}n_{A}=30 \\
\bar{X}_{A_{1}}=66,67 \\
s_{A}^{2}=129,89\end{array}$ & $\begin{array}{l}n_{A_{1}}=30 \\
\bar{X}_{A_{1}}=59,67 \\
s_{A_{1}}^{2}=234,37\end{array}$ & $\begin{array}{l}n_{T}=60 \\
\bar{X}_{T}=63,17 \\
s_{T}^{2}=191,50\end{array}$ \\
\hline
\end{tabular}

\section{Pengujian Persyaratan Analisis}

Untuk mengetahui apakah sampel berasal dari populasi terdistribusi normal atau tidak, maka dilakukan uji normalitas dengan menggunakan Program SPSS 15.0. Adapun outputnya dapat dilihat pada Tabel 3 berikut ini. 
Tabel 3. Output SPSS Uji Normalitas

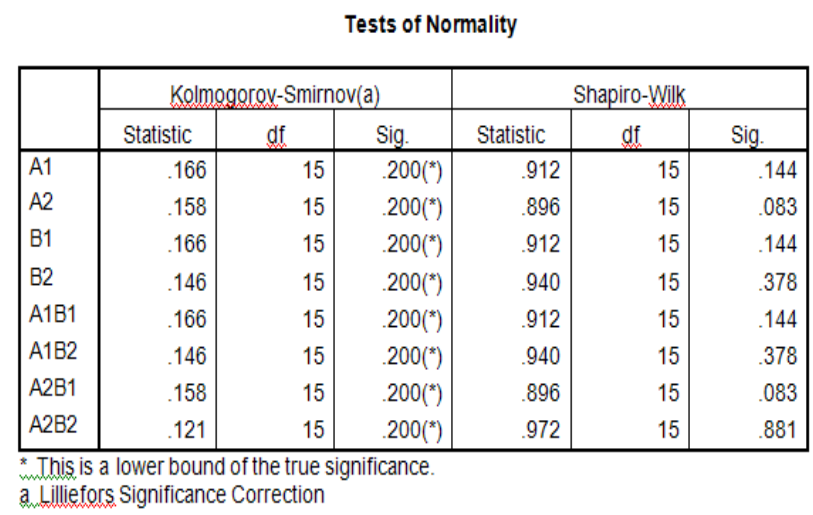

Berdasarkan output di atas, maka ke- 8 kelompok tersebut berdistribusi normal. Hal ini dikarenakan Sig. dalam Kolmogorov-Smirnov >0,05.

Selain uji normalitas, salah satu syarat yang diperlukan dalam menganalisis data dengan menggunakan ANOVA adalah uji homogenitas. Adapun tujuan uji homogenitas adalah untuk mengetahui apakah varians populasi bersifat homogen atau tidak. Pengujian homogenitas dilakukan menggunakan program SPSS 15.0. Adapun outputnya dapat dilihat pada Tabel 4 berikut ini.

Tabel 4. Output SPSS Uji Homogenitas

Test of Homogeneity of Variances

\begin{tabular}{|c|c|c|c|}
\hline $\begin{array}{l}\text { Levene } \\
\text { Statistic }\end{array}$ & df1 & $\mathrm{df} 2$ & Sig. \\
\hline .534 & 3 & 56 & .661 \\
\hline
\end{tabular}

Berdasarkan output tersebut, maka sampel berasal dari populasi yang memiliki varians homogen. Hal ini dikarenakan Sign. nya $>0,05$.

Dari pengujian normalitas dan homogenitas di atas dapat disimpulkan bahwa persyaratan yang harus dipenuhi oleh data penelitian yang akan diolah dengan teknik ANOVA sudah terpenuhi.

\section{Pengujian Hipotesis}

Setelah dilakukan uji normalitas dan homogenitas dan hasilnya menunjukkan bahwa sampel penelitian berasal dari populasi berdistribusi normal dan varians sampel homogen, maka pengujian hipotesis dengan menggunakan ANOVA dapat dilakukan.

Analisis terhadap data Kemampuan Pemecahan Masalah Matematika dilakukan dengan menggunakan ANOVA dua arah yang proses perhitungannya dibantu dengan program SPSS 15.0. Hasil uji ANOVA tersebut kemudian dilanjutkan dengan uji $t$ untuk mengetahui signifikansi perbedaan diantara masing-masing kelompok secara signifikan (simple effect). Dengan kata lain, uji $t$ digunakan dengan tujuan untuk melihat kelompok sampel mana yang lebih tinggi Kemampuan Pemecahan Masalah Matematika.

Dengan menggunakan program SPSS 15.0, diperoleh output sebagai berikut. 
Tabel 5. Output SPSS ANOVA

\begin{tabular}{|c|c|c|c|c|c|}
\hline Source & $\begin{array}{l}\text { Type III Sum } \\
\text { of Squares }\end{array}$ & df & Mean Square & $\mathrm{F}$ & Sig. \\
\hline Corrected Model & 5898.333(a) & 3 & 1966.111 & 20.389 & .000 \\
\hline Intercept & 239401.667 & 1 & 239401.667 & 2482.684 & .000 \\
\hline model _pmblijn & 735.000 & 1 & 735.000 & 7.622 & .008 \\
\hline asesmen knri & 481.667 & 1 & 481.667 & 4.995 & .029 \\
\hline $\begin{array}{l}\text { model_pmblijn * } \\
\text { asesmen knri }\end{array}$ & 4681.667 & 1 & 4681.667 & 48.551 & .000 \\
\hline Error & 5400.000 & 56 & 96.429 & & \\
\hline Total & 250700.000 & 60 & & & \\
\hline Corrected Total & 11298.333 & 59 & & & \\
\hline
\end{tabular}

Berdasarkan Hasil uji ANOVA tersebut, terlihat bahwa Sign. dari model_pmbljrn*asesmen_knrj < 0,05 sehingga harus dilanjutkan dengan uji $t$ (uji lanjut) untuk mengetahui signifikansi perbedaan diantara masing-masing kelompok secara signifikan (simple effect). Dengan menggunakan program SPSS 15.0, diperoleh output sebagai berikut.

Tabel 6. Output SPSS Uji Lanjut (t)

\begin{tabular}{|c|c|c|c|c|c|c|c|c|}
\hline & \multicolumn{5}{|c|}{ Paired Differences } & $t$ & df & Sig. (2-tailed) \\
\hline & \multirow{2}{*}{$\begin{array}{l}\text { Mean } \\
\text { Lower }\end{array}$} & \multirow{2}{*}{\begin{tabular}{c|} 
Std. \\
Deviation \\
Upper \\
\end{tabular}} & \multirow{2}{*}{$\begin{array}{c}\text { Std. Error } \\
\text { Mean } \\
\text { Lower }\end{array}$} & \multicolumn{2}{|c|}{$\begin{array}{c}\text { 95\% Confidence Interval } \\
\text { of the Difference }\end{array}$} & \multirow{2}{*}{$\begin{array}{l}\text { Mean } \\
\text { Upper }\end{array}$} & \multirow{2}{*}{\begin{tabular}{|c|}
$\begin{array}{c}\text { Std. } \\
\text { Deviation }\end{array}$ \\
Lower \\
\end{tabular}} & \multirow{2}{*}{$\begin{array}{c}\begin{array}{c}\text { Std. Error } \\
\text { Mean }\end{array} \\
\text { Upper } \\
\end{array}$} \\
\hline & & & & Upper & Lower & & & \\
\hline $\begin{array}{ll}\text { Pair } & \text { A1B1- } \\
& \text { A1B2 }\end{array}$ & -12.00000 & 3.68394 & .95119 & -14.04010 & -9.95990 & -12.616 & 14 & .000 \\
\hline $\begin{array}{ll}\text { Pair 2 } & \text { A2B1- } \\
& \text { A2B2 }\end{array}$ & 23.33333 & 4.08248 & 1.05409 & 21.07253 & 25.59414 & 22.13| & 14 & .000 \\
\hline $\begin{array}{ll}\text { Pair } 3 & \text { A1B1. } \\
& \text { A2B1 }\end{array}$ & -10.66667 & 3.19970 & .82616 & -12.43860 & -8.89473 & -12.911 & 14 & .000 \\
\hline $\begin{array}{ll}\text { Pair } 4 & \text { A1B2- } \\
& \text { A2B2 }\end{array}$ & 24.66667 & 2.96808 & .76636 & 23.02300 & 26.31034 & 32.187 & 14 & .000 \\
\hline
\end{tabular}

Berdasarkan perhitungan yang disajikan sebelumnya, terlihat bahwa :

1) Kemampuan pemecahan masalah matematika untuk mahasiswa yang memperoleh pembelajaran dengan model kooperatif lebih tinggi dibandingkan mahasiswa yang memperoleh pembelajaran dengan model klasikal dalam mata kuliah Kalkulus (sign. model_pembljrn < 0.05 dalam ANOVA). Hal ini dikarenakan pembelajaran kooperatif meningkatkan kemampuan mahasiswa sebagai hasil dari tingkatan relasi antar kelompok dalam menyelesaikan masalah, khususnya masalah matematika dalam mata kuliah Kalkulus.

2) Kemampuan pemecahan masalah matematika untuk mahasiswa yang diberi asesmen kinerja holistik dari Lane lebih tinggi dibandingkan mahasiswa yang diberi asesmen kinerja menurut Polya dalam mata kuliah Kalkulus (sign. asesmen_knrj < 0.05 dalam ANOVA). Hal ini dikarenakan asesmen kinerja holistik dari Lane menerapkan pengetahuan strategi penyelesaian masalah. Hal inilah yang membuat asesmen kinerja holistik dari Lane memiliki kontribusi yang besar dalam meningkatkan kemampuan pemecahan masalah matematika pada mata kuliah Kalkulus. 
3) Adanya interaksi antara penggunaan model pembelajaran dan asesmen kinerja terhadap kemampuan pemecahan masalah matematika dalam mata kuliah Kalkulus. Hal ini terlihat dari nilai sign. model_pmbljrn*asesmen_knrj $<0.05$ dalam ANOVA. Apabila interaksi tersebut digambarkan dalam bentuk grafik maka terjadi persilangan/perpotongan antara garis-garis yang menghubungkan rerata skor kemampuan pemecahan masalah matematika pada model pembelajaran dan asesmen kinerja.

4) Pada kelompok mahasiswa yang memperoleh pembelajaran dengan model kooperatif, kemampuan pemecahan masalah matematika untuk mahasiswa yang diberi asesmen kinerja holistik dari Lane lebih rendah dibandingkan mahasiswa yang diberi asesmen kinerja menurut Polya dalam mata kuliah Kalkulus (sign. $A 1 B 1-A 1 B 2<0.05$ dalam Uji $t$ ). Hal ini dikarenakan asesmen kinerja menurut Polya sangat mendukung model pembelajaran kooperatif. Karakteristik yang dimaksud adalah penilaian kemampuan mahasiswa dalam menyelesaikan masalah atau tugas matematika melalui 4 tahap, yaitu: (1) memahami masalah, (2) merencanakan prosedur penyelesaian, (3) melaksanakan rencana, serta (4) memeriksa hasil dan proses.

5) Pada kelompok mahasiswa yang memperoleh pembelajaran dengan model klasikal, kemampuan pemecahan masalah matematika untuk mahasiswa yang diberi asesmen kinerja holistik dari Lane lebih tinggi dibandingkan mahasiswa yang diberi asesmen kinerja menurut Polya dalam mata kuliah Kalkulus (sign. $A 2 B 1-A 2 B 2<0.05$ dalam Uji $t$ ). Apabila diamati karakteristik dari asesmen kinerja secara holistik dari Lane terdiri dari 3 langkah, yaitu mengidentifikasi pengetahuan matematika, menentukan dan menerapkan pengetahuan strategi penyelesaian masalah, serta mengkomunikasikan hasil penyelesaian masalah. Hal inilah yang membuat asesmen kinerja holistik dari Lane memiliki kontribusi yang besar dalam meningkatkan kemampuan pemecahan masalah matematika pada mata kuliah Kalkulus dalam model pembelajaran klasikal.

6) Pada kelompok mahasiswa yang diberi asesmen kinerja holistik dari Lane, kemampuan pemecahan masalah matematika untuk mahasiswa yang memperoleh pembelajaran dengan model kooperatif lebih rendah dibandingkan mahasiswa yang memperoleh pembelajaran dengan model klasikal dalam mata kuliah Kalkulus (sign. A1B1- A2B1 $<0.05$ dalam Uji $t$ ). Hal ini dikarenakan karakteristik dari asesmen kinerja secara holistik dari Lane memiliki kontribusi yang besar dalam meningkatkan kemampuan pemecahan masalah matematika pada mata kuliah Kalkulus dalam model pembelajaran klasikal yaitu mengidentifikasi pengetahuan matematika, menentukan dan menerapkan pengetahuan strategi penyelesaian masalah, serta mengkomunikasikan hasil penyelesaian masalah.

7) Pada kelompok mahasiswa yang diberi asesmen kinerja menurut Polya, kemampuan pemecahan masalah matematika untuk mahasiswa yang memperoleh pembelajaran dengan model kooperatif lebih tinggi dibandingkan mahasiswa yang memperoleh pembelajaran dengan model klasikal dalam mata kuliah Kalkulus (sign. A1B2-A2B2 $<0.05$ dalam Uji $t$ ). Hal ini dikarenakan karakteristik dari asesmen kinerja menurut Polya memiliki kontribusi yang besar dalam meningkatkan kemampuan pemecahan masalah matematika pada mata kuliah Kalkulus dalam model pembelajaran kooperatif yaitu memahami masalah, merencanakan prosedur penyelesaian, melaksanakan rencana, serta memeriksa hasil dan proses. 


\section{PENUTUP}

\section{Kesimpulan}

1) Kemampuan pemecahan masalah matematika untuk mahasiswa yang memperoleh pembelajaran dengan model kooperatif lebih tinggi dibandingkan mahasiswa yang memperoleh pembelajaran dengan model klasikal dalam mata kuliah Kalkulus.

2) Kemampuan pemecahan masalah matematika untuk mahasiswa yang diberi asesmen kinerja holistik dari Lane lebih tinggi dibandingkan mahasiswa yang diberi asesmen kinerja menurut Polya dalam mata kuliah Kalkulus.

3) Adanya interaksi antara penggunaan model pembelajaran dan asesmen kinerja terhadap kemampuan pemecahan masalah matematika dalam mata kuliah Kalkulus.

4) Pada kelompok mahasiswa yang memperoleh pembelajaran dengan model kooperatif, kemampuan pemecahan masalah matematika untuk mahasiswa yang diberi asesmen kinerja holistik dari Lane lebih rendah dibandingkan mahasiswa yang diberi asesmen kinerja menurut Polya dalam mata kuliah Kalkulus.

5) Pada kelompok mahasiswa yang memperoleh pembelajaran dengan model klasikal, kemampuan pemecahan masalah matematika untuk mahasiswa yang diberi asesmen kinerja holistik dari Lane lebih tinggi dibandingkan mahasiswa yang diberi asesmen kinerja menurut Polya dalam mata kuliah Kalkulus.

6) Pada kelompok mahasiswa yang diberi asesmen kinerja holistik dari Lane, kemampuan pemecahan masalah matematika untuk mahasiswa yang memperoleh pembelajaran dengan model kooperatif lebih rendah dibandingkan mahasiswa yang memperoleh pembelajaran dengan model klasikal dalam mata kuliah Kalkulus.

7) Pada kelompok mahasiswa yang diberi asesmen kinerja menurut Polya, kemampuan pemecahan masalah matematika untuk mahasiswa yang memperoleh pembelajaran dengan model kooperatif lebih tinggi dibandingkan mahasiswa yang memperoleh pembelajaran dengan model klasikal dalam mata kuliah Kalkulus.

\section{Saran}

1) Dosen hendaknya menggunakan asesmen kinerja dalam setiap mata kuliah yang diampunya.

2) Mengingat masih banyak hal yang harus diperbaiki dalam meningkatkan kemampuan pemecahan masalah matematika, maka diperlukan penerapan model pembelajaran dan asesmen kinerja yang tepat.

3) Agar memperoleh hasil yang komprehensif mengenai model pembelajaran, asesmen kinerja, dan kemampuan pemecahan masalah matematika, disarankan untuk melakukan penelitian lebih lanjut.

\section{DAFTAR PUSTAKA}

Baroody, A.J. dan R.T.C. Niskayuna. 1993. Problem Solving, Reasoning and Communicating. New York : Macmillan Publishing.

Bell, F.H. 1978. Teaching and Learning Mathematics in Secondary School. New York: Brown Company Publisher.

Chang, E dan D. Simon. 1999. The Circle of Learning : Individual and Group Process. (http://olam.ed.asu/epaa/v5n7/). Diakses tanggal 2 Maret 2009.

Cooney, T.J. dkk. 1975. Dynamic Teaching Secondary School Mathematics. Boston: Houghton Miffin Company.

Dess, R.L. 1996. The role of cooperative learning in increasing problem solving ability in a college remedial course. Journal for Research in Mathematics Education: 5. 
Ghozali, Imam. 2006. Aplikasi Analisis Multivariate dengan Program SPSS. Semarang: Universitas Diponegoro Press.

Greenes, C dan L. Schulman. 1996. Communication Process in Mathematical Explorations and Investigations. Reston VA: NCTM.

Hawton, J. 1992. Problem Solving - Its Place in The Math Program. Melbourne : The Mathematical Association of Victoria.

Hengenson, S.L. 1992. Problem Solving Research in Middle Junior High School Science Education. Colubus : The Ohio State University.

Hilke, E.V. 1994. Cooperative Learning. Indiana : Phi Delta Kappa E.F.

Huba, M.E. dan J.E Freed. 1999. Assessment of Teaching and Learning Etymology of The Word: Assessment. (http://usc.edu/programs/cet/resources/assessment/). Diakses tanggal 12 Februari 2009.

Hudoyo, Herman. 1990. Strategi Mengajar Matematika. Malang : IKIP Malang.

Johnson, David dan R.T. Johnson. 1987. Learning Together and Alone : Cooperative, Competitive and Individualistic. New Jersey : Prentice Hall.

Joyce, Bruce dan Marsha Weil. 1996. Model of Teaching. Needham Heights : Asimon dan Schuster Company.

Lane, S. 1992. The Conceptual Framework for the Development of a Mathematics Performance Instrument. National Council on Measurement in Education.

Nitko, A.J. 1996. Educatioal Assessment of Student $3{ }^{\text {rd }}$ Ed. New Jersey : Prentice Hall.

Poly, Cal. 1999. Cal Poly's Learning Assessment Development Plan. (http://academicprograms.calpoly.edu/assessment/documents/CP_AssmnPlant.pd f). Diakses tanggal 15 Maret 2009.

Polya, G. 1981. Mathematical Discovery : On Understanding, Learning, and Teaching Problem Solving. New York : John Wiley Inc.

--------. 1985. How to Solve It. A New Aspect of Mathematical Methods. New Jersey : Pearson Education Inc.

Reigeluth. C.M. 1983. Instructional Design Theories and Models : Interview of Their Current Status. London : Lawrence E.A.Publisher.

Ruseffendi, H.E.T. 1988. Pengantar Membantu Guru Mengembangkan Kompetensinya dalam Pengajaran Matematika untuk Meningkatkan CBSA. Bandung : Tarsito.

Sasmoko. 2004. Metode Penelitian. Jakarta : UKI Press.

Schoen, H.L. dkk. 1989. Embedding Communication Throughout The Curriculum. Reston VA : NCTM.

Stahl, R.J. 1994. Cooperative Learning Social Studies. New York : Addison Wesley.

Stewart, James. 2003. Kalkulus Jilid 1. Jakarta : Erlangga.

Sudjana. 1996. Metode Statistika. Edisi ke-6. Bandung : Tarsito.

Sulivan, P dan J. Mousley. 1996. Natural Communication in Mathematics Classroom : What Does It Look Like?. Melbourne : Merga.

Sumaryoto, dkk. 2008. Pedoman Operasional Tahun Akademik 2008/2009. Jakarta : Universitas Indraprasta PGRI.

Supardi. 2008. Diktat Kuliah : Aplikasi Statistik dalam Penelitian Pendidikan. Jakarta : Program Pasca Sarjana UNINDRA.

Zainul, Asmawi. 2004. Asesmen Alternatif untuk Belajar dan Pembelajaran. Makalah disampaikan dalam Seminar Nasional HEPI 26-27 Maret 2004 di Yogyakarta.

Zimaro, D.M. 1999. Realistic Mathematics Education. (http://geocities.com/ratuilma/). Diakses tanggal 2 Januari 2009. 